University of Wollongong

Research Online

Faculty of Social Sciences - Papers (Archive) Faculty of Arts, Social Sciences \& Humanities

2017

\title{
Manufacturing and cultural production: Towards a progressive policy agenda for the cultural economy
}

Carl Grodach

Queensland University of Technology

Justin O'Connor

Monash University

Christopher R. Gibson

University of Wollongong, cgibson@uow.edu.au

Follow this and additional works at: https://ro.uow.edu.au/sspapers

Part of the Education Commons, and the Social and Behavioral Sciences Commons

Research Online is the open access institutional repository for the University of Wollongong. For further information contact the UOW Library: research-pubs@uow.edu.au 


\title{
Manufacturing and cultural production: Towards a progressive policy agenda for the cultural economy
}

\author{
Abstract \\ Urban policy-makers have largely treated the cultural economy as either an appendage of a larger creative \\ or knowledge-based economy or as a means of enhancing consumption. The result has been a focus on \\ programs to attract highly educated and skilled professionals often at the expense of attention to \\ workforce inequality, manual workers and skills, gentrification, and the displacement of small, \\ independent manufacturing businesses. In the context of growing labour market inequality and deepening \\ urban cultural schisms, this paper seeks to redirect urban and cultural policy toward a more progressive \\ research and policy agenda centered on material cultural production. Our point of departure is to focus on \\ the nascent intersection between the cultural economy and small manufacturing. This paper first \\ provides a brief summary of the current approaches to urban policy and the cultural economy and the \\ factors that have shaped policy decisions. Next, we discuss emerging attention around an alternative \\ urban cultural policy agenda geared toward the cultural industries, small manufacturing, and craft-based \\ production. Finally, we explore the relationships among cultural industries and small manufacturers and \\ discuss the key research gaps and policy issues that will affect relationships and development oriented to \\ cultural production and manufacturing at the city-region level.

\section{Disciplines} \\ Education | Social and Behavioral Sciences

\section{Publication Details} \\ Grodach, C., O'Connor, J. \& Gibson, C. (2017). Manufacturing and cultural production: Towards a \\ progressive policy agenda for the cultural economy. City, Culture and Society, 10 17-25.
}




\title{
Manufacturing and Cultural Production: Towards a progressive policy agenda for the cultural economy
}

Carl Grodach, Queensland University of Technology (corresponding author, carl.grodach@qut.edu.au)

Justin O'Connor, Monash University

Chris Gibson, University of Wollongong

\begin{abstract}
Urban policy-makers have largely treated the cultural economy as either an appendage of a larger creative or knowledge-based economy or as a means of enhancing consumption. The result has been a focus on programs to attract highly educated and skilled professionals often at the expense of attention to workforce inequality, manual workers and skills, gentrification, and the displacement of small, independent manufacturing businesses. In the context of growing labour market inequality and deepening urban cultural schisms, this paper seeks to redirect urban and cultural policy toward a more progressive research and policy agenda centered on material cultural production. Our point of departure is to focus on the nascent intersection between the cultural economy and small manufacturing. This paper first provides a brief summary of the current approaches to urban policy and the cultural economy and the factors that have shaped policy decisions. Next, we discuss emerging attention around an alternative urban cultural policy agenda geared toward the cultural industries, small manufacturing, and craft-based production. Finally, we explore the relationships among cultural industries and small manufacturers and discuss the key research gaps and policy issues that will affect relationships and development oriented to cultural production and manufacturing at the city-region level.
\end{abstract}

Keywords: cultural economy, cultural industries, creative economy, cultural policy, manufacturing, craft, urban policy 


\section{Introduction}

Policies aimed at the cultural economy have come to play an integral role in the urban development strategies of cities around the globe (Grodach and Silver, 2014; Hutton, 2008; Scott, 2004; Van Heur, 2010). ${ }^{1}$ Yet, conceptions of what constitutes the cultural economy remain polyvalent, meaning that policy imaginations, and resulting implementations, are fluid and divergent (Gibson 2012). Urban policy-makers have turned toward and interpreted the cultural economy in two primary ways: as an appendage of a larger creative or knowledge economy or as a means of enhancing consumption (Evans 2009). Over the last decades, such attempts have been part of strategies to assist cities to cope with economic restructuring, support the growth of professional jobs, and redevelop central city buildings, infrastructure and real estate markets. However, this has also contributed to the parallel development of largely lower wage service jobs for those without the skills and education to work in the creative economy (Davidson and Wyly 2012), as well as gentrification and the displacement of residents and businesses from central city areas (Davidson 2007; Hutton 2008; Catungal, Leslie and Hii, 2009). Creative industries and consumption-focused interpretations of the cultural economy have contributed to the growing polarisation of cities, culturally and economically.

Policy discourses informing such urban transitions have thus been widely criticized for implying that industrial and manufacturing workers and members of residual inner-city working-class and migrant communities are 'outmoded', or even 'uncreative', needing to be replaced by more 'talented' outsiders (Barnes et al 2006; Wilson and Keil 2008). Moreover, the focus on the cultural economy as either consumption-based or as a facet of the knowledge economy has directed policy away from the employment and development opportunities related to cultural production- in the sense of the material prototyping, manufacture and assembly of physical goods infused with cultural or semiotic meaning.

At the same time that cities have sought to jettison manufacturing legacies and land uses, there is a renewed public and policy interest in 'making things' (Anderson 2012; Berger 2013; Westbury 2015), encompassing additive manufacturing, bespoke making, and craftbased production. Opportunities abound to pursue urban economic development strategies that build upon, rather than eschew, industrial, migrant and working-class skills and legacies (Gibson 2016), but they may be overlooked within constrained cultural economic policymaking overly focused on the so-called knowledge and creative industries.

In response, this paper seeks to redirect urban and cultural policy toward a more progressive research and policy agenda centered on material cultural production. As we discuss, key social and economic trends have positioned cultural and craft production as a significant but overlooked opportunity for more equitable urban economic development. Simultaneously, this is a chance for cultural policy to reinvent itself following a decade or more of consumption-based creative city strategizing. Our point of departure is to focus on the growing intersection between the cultural economy and small manufacturing. Research has recognized the changing nature and growth of urban manufacturing (Friedman and Byron, 2012; Helper, Kreuger, and Weil, 2012; Mistry and Byron, 2011; Sassen, 2010), but few specifically concentrate on the relationships with the cultural industries (Gibson, Carr, and

\footnotetext{
${ }^{1}$ The cultural economy encompasses the production, distribution, and consumption of goods and services based primarily on aesthetic or symbolic value (Scott 2000). This covers a range of sectors in the visual and performing arts, music, fashion, design (e.g. architecture, graphic design), and media (e.g. film, television, radio, video games, book publishing).
} 
Warren, 2015; Gu, 2014). Many have studied the cultural industries as a production system, acknowledging the cultural economy's links to material manufacture (e.g. Scott, 2000; Pratt, 2005) and there is growing attention to independent craft activity (Anderson 2012; Jakobs, 2012; Luckman, 2015; Thomas et al., 2013), but little work has been devoted to the ways in which cultural industries interact with and perform manufacturing functions.

This paper first provides a brief summary of the current approaches to urban policy and the cultural economy and the factors that have shaped policy decisions. Next, we discuss emerging attention around an alternative urban cultural policy agenda geared toward the cultural industries, small manufacturing, and craft-based production. Finally, we explore the relationships among cultural industries and small manufacturers and discuss the key research gaps and policy issues that will affect relationships and development oriented to cultural production and manufacturing at the city-region level. Our contention is that more progressive alternatives to existing urban policy for the cultural economy should explore the interface between small manufacturing and cultural industries, and acknowledge and build upon both industrial and cultural legacies, with their associated human capacities. This, we argue, is necessary not just to remedy the false ontological severing of manual and cerebral/creative tasks within conceptions of economy (Carr and Gibson 2016), but to pursue more equitable futures for cities that seem now more culturally, economically and spatially fractured than ever.

\section{Urban Policy and the Cultural Economy: Knowledge Industries and Consumption}

Two dominant narratives have driven urban policy around the cultural economy. One narrative frames the cultural economy as a subset of a knowledge or creative economy. The other narrative treats arts and culture primarily as consumption amenities that will attract development and improve the city image. Both consist of urban and cultural policies that directly and indirectly target cultural activities and fail to account for the roles and values of cultural production, and of industrial places and people.

Under the rubric of 'creative industries,' the cultural economy has been positioned as a central part of a 'knowledge economy' defined by advanced services, information technologies, and a workforce high in human capital (Howkins, 2003; Potts, 2012). The rise of knowledge and innovation-driven industries has defined urban economic restructuring since at least the 1980s. This growth is typically framed as a response to the deindustrialisation and loss of employment in older, heavy manufacturing industries in most OECD countries. It is also a specifically urban process. The high level of transactions and coordination necessary to manage the global dispersal of industry and trade necessitates that the intricate network of finance, legal, design, and other knowledge and creative industry services concentrate in specific places (Sassen, 2012; Scott, 2006; Watson 2008).

Policy around this narrative typically does not directly target cultural industry development, but is rather geared toward remaking the CBD for the knowledge industries and advanced business services more broadly. Cities have implemented an array of incentive-based, property-led development strategies through tax abatements, property write-downs, and land assembly to make their CBDs attractive to these industries and to enable large-scale redevelopment. These strategies are ubiquitous in global hubs as well as the 'shrinking cities' that continue to struggle with their industrial legacy, despite evidence that these strategies do not have a major impact on business location decisions (Grodach and Ehrenfeuct, 2016; Hackworth, 2014; Kenyon, Langley, and Paquin 2012). 
The rapid growth of CBD office development and the rehabilitation of buildings for knowledge economy activity in turn has generated demand for central city neighborhoods by professionals employed in knowledge-based services and corporate creative industries (Butler and Lees 2006). Struggling areas in many cities have experienced a demographic shift and redevelopment by and for upwardly mobile residents. Homeownership in the urban core has increased as abandoned and historic buildings have been renovated and new retail and entertainment projects have been developed (Beauregard 2005). With these shifts have come rising property values, lower vacancy rates and new sources of much needed revenue for cities. Meanwhile, in cities where vacancy rates are much lower (especially in Europe and Australia), urban land previously zoned for industrial purposes (and still sufficiently occupied by small manufacturing firms) has also declined, after being caught up in an accumulation strategy geared around developers and local municipal authorities working in collaboration to encourage a shift to mixed-land use designation (Shaw 2015). The shift to mixed-land use zoning - frequently justified as replacing 'dirty' industry with more attractive, 'cleaner' city spaces and industries - has the effect of rising potential rent returns per square metre by demolishing existing low-rise industrial buildings and replacing them with higher-density residential apartment developments (Shaw 2015). The result of this is the further gradual evacuation of small manufacturing from the inner city.

These trends warrant critique, not just for the missed economic opportunities that stem from the revival in manufacturing and 'making' cultures, but also for the degree to which they intersect negatively with urban labor market characteristics, exacerbating social inequalities (Leslie and Catungal 2012). With the evacuation of manufacturing, lost are relatively wellpaid jobs that build upon manual skills (Warren 2015). While the growth of knowledge industries has enhanced urban economic development in many places, it has in turn generated demand for lower-wage services that offer few career opportunities compared to the lost industrial manufacturing jobs. In countries such as the US, African-Americans and other minority groups have been hit particularly hard due to the racial and ethnic stratification of urban labor markets combined with enduring segregation that created unequal opportunity (Wilson 2009). In the United Kingdom the widespread promotion of creative industries as urban regeneration has overlaid existing entrenched class divisions, rather than replaced them - exacerbating social inequality (Hudson 2005; Oakley 2006; Davidson and Wyly 2012). Framing the creative economy around primarily knowledge industries in these regeneration strategies across many places has thus contributed to a bifurcated and polarized economy of highly skilled professionals working in the knowledge economy and often minority and immigrant workforce in the lower wage services industries.

Related to this, a second policy stream looks to the cultural economy to drive consumption and play a role in place branding. Local governments now routinely approach culture as an amenity to attract tourists, increase consumption spending, and improve the city image (Grodach and Loukaitou-Sideris, 2007; Oakley and O’Connor, 2015). Cities across the world have spent considerable sums of money to develop arts and entertainment precincts with flagship cultural destinations, galleries, and cafes. Additionally, following Richard Florida's (2002) creative class thesis, urban cultural policy in many cities has to varying degrees relied on arts and cultural activities as consumption amenities to attract mobile knowledge workers (Atkinson and Easthope, 2009; Grodach, 2013). Many CBD redevelopment strategies such as Melbourne's focus on the development of new housing and consumption spaces in laneway cafes and boutiques or Austin, Texas' branding around live music have evolved to capitalize on this urban cultural policy mode. Urban cultural policy in these and many other cities does 
not uniformly follow this approach (O’Connor and Gu, 2010; Grodach and Silver, 2014; Shaw, 2014). However, the logic of attracting the creative class through spaces of consumption has had a significant impact on gentrifying the urban core and contributing to the displacement of residents and small, independent, and artistic businesses (Catungal, Leslie, \& Hii, 2009; Curren, 2010; Grodach, 2012, 2013; Ponzini \& Rossi, 2010; Shaw, 2013). Moreover, as with the rise of knowledge and creative industries, consumption destinations for tourists and the creative class actually create few stable, career jobs for working-class and minority residents and often have limited economic impact (Grodach, 2010; Noonan, 2013). These strategies focus on encouraging local spending, but have yet to address the cost of mounting workforce inequality discussed above.

Taken together, these policy narratives position the cultural economy as largely one focused around ideas and intellectual property within a larger creative or knowledge economy and as a source of consumption and tourism. In both instances, the cultural economy is framed as a replacement for an outmoded manufacturing economy (O’Connor and Gu 2014a) and a means of redeveloping under-valued land in the urban core. This has exacerbated uneven urban development while threatening segments of the cultural economy workforce itselfespecially the 'independent' subcultures at the heart of many forms of cultural innovation (Shaw 2013)- thus undermining the gains from existing cultural economy policy.

\section{A Third Policy Narrative for the Cultural Economy?: Cultural Production and Small Manufacturing}

With these two streams dominating thinking around urban policy and the cultural economy, many cities have missed opportunities to nurture and develop cultural production industries in their own right. Despite the substantial attention to the cultural economy, cities have done little to encourage and support cultural production activities or encourage linkages with regional industries outside the knowledge-based sectors.

An emerging discussion around the cultural economy stresses the importance of cultural production specifically in relation to small urban manufacturing and craft-based industries. This approach differs from the established research on the cultural industries as a production system (Pratt, 2005; Scott, 2004, 2008) in that there is a specific emphasis on reconceptualising the cultural economy in relation to manufacturing and 'making things' (Carr and Gibson, 2016; Gibson, Carr, and Warren, 2015). This also connects with a revived interest in craft activity (Anderson 2012; Heying, 2010; Jakobs, 2012; Luckman, 2012, 2015; Sennett, 2008; Thomas et al., 2013). However, much of the work on craft focuses on traditional craft skills and small, independent and home-based work or on small-scale adaption of 'hacking' of new technologies (Morozov, 2014). What is largely missing is a synthetic examination of the reindustrialization of the cultural economy and the ramifications for urban and cultural policy. This has begun with calls to move beyond the 'replacement narrative' that dominates thinking around the cultural economy (O'Connor and Gu, 2014a). Similarly, there are arguments for rethinking the splintering of design and production and the opposition of knowledge and 'material economies' that has emerged from the focus on coping with deindustrialization through the knowledge and creative industries (Hudson, 2012; Sassen, 2010).

Reframing the cultural economy around manufacturing and craft production stems from a larger reconceptualization and recognition of the changing nature of manufacturing itself. Major plant closures still dominate the headlines in some countries promulgating the 
discourse that manufacturing industries are in a 'natural' state of decline (Carr and Gibson, 2016). However, manufacturing is no longer defined primarily by large-scale industrial production, heavy machinery and massive infrastructure. Despite the headlines of job losses in large firms, SMEs with fewer than 50 employees make up the vast majority of manufacturing firms in the United States (Mistry and Byron, 2011) and a majority of firms in Australia (Gibson and Warren 2013), and elsewhere.

Indeed, while few predict a comeback of large-scale mass production industries, new studies point toward the growing importance of small, flexible and regionally-specific manufacturers (Bryson et al 2008; Bryson and Ronayne 2012; Jacobs, 2010; Mistry and Byron, 2011; Sassen, 2010). This is significant because these types of manufacturing can provide stable, higher-quality and more accessible employment than tourism and consumption-orientated redevelopment. And, it is work that is not easily outsourced. Unlike traditional manufacturing industries that compete on cost or volume, small manufacturers and cultural production firms alike compete on innovative design, product differentiation, and specialize in customized production (Warren and Gibson 2013). As a result, these firms tend to be highly place-bound and locally-integrated (O’Connor, 2004; Pratt, 2004; Scott, 2000, 2006; Warren and Gibson, 2014). And, when owned by employees themselves, small manufacturers tend to be more innovative, and thus resilient to wider market volatility (Koski et al 2012). Possibilities exist for more equitable and collaborative forms of enterprise development in small-scale cultural production, compared with the corporate investment in knowledge, finance, property and consumption sectors that typically dominate regeneration strategies (Clark 2012; 2014). Additionally, small manufacturing enterprises have been shown to make important contributions to environmental sustainability, commercial innovation, and exports (Helper, Kreuger, and Weil, 2012; Prime Minister's Manufacturing Taskforce, 2012).

Much of the growth in small manufacturing is tied to design, cultural and craft-based production industries (Hatch, 2013). Importantly, this encompasses more than boutique 'makers' or the consumption-orientated branding of 'maker' spaces. Firms in these sectors serve a variety of markets and consumers and, therefore, play a vital role in both advanced services and consumption economies alike. Collectively, they are also an economic driver in their own right that can generate a range of skilled employment, investment, and provide important diversity to the economic base. For example, many cultural industries look to local manufacturing and craft industries to supply crucial materials and components (Thomas et al., 2013). Architecture firms may rely on metal-workers and foundries for specialized building components or industrial designers may look to ceramics manufacturers to fabricate special containers and display cases. In addition, cultural industries often require specialized craft and manufacturing skills and services. For example, film and theatre producers rely on the expertise of set designers and woodworkers. Moreover, important niche markets with strong local and culturally specific profiles develop around the products of small manufacturers and craft producers including clothing, furniture, jewelry, and artisanal food products. Former industrial districts have become hubs of cultural production such as the Greenpoint Manufacturing \& Design Center or the Brooklyn Navy Yard in New York. Numerous support organizations have emerged to represent urban manufacturers including SFMade, Portland Made, Urban Manufacturing Alliance, Made in NYC, or Philadelphia’s Urban Industry Initiative. All of this draws on and seeks to support existing manufacturing and craft skill-sets rather than displacing this labor to a consumer-based service economy. Examples in Australia and the UK include Adelaide’s Jam Factory, Sydney’s Danks Street cluster, and organisations like Craft Queensland and the UK Crafts Council, but these tend to revolve around individual artisans rather than cultivating the cultural industry-manufacturing nexus. 
Attention to small manufacturing is not new. However, much has changed since the pioneering work of Piore and Sabel (1984) on spaces of craft-based making in the 'Third Italy'. As we note above, cultural and craft manufacturers service markets around consumption and creative economies, but they are considerably more developed today than in the 1980s. The rapid rise of 'localist' movements defined by fair trade, local consumption and customized products likewise creates new opportunities for the development and expansion of cultural and craft production industries (Causey, 2014). Further, the development of new, advanced manufacturing technologies allows entirely new forms of manufacture and niche production (Anderson, 2012). At the same time, rising energy and transport costs have to some extent offset higher labor costs in countries like Australia and the US, while enabling manufacturers to better capitalize on regionally embedded networks of production. These changes alter the dynamics and conditions for small manufacturing and cultural production. And yet, urban policy-makers continue to promulgate the 'replacement' narrative, assuming manufacturing is in inevitable decline, and miss opportunities to connect diverse small manufacturing enterprises and extant industrial legacies to the cultural and creative sectors. We call for enhanced attention to the land use, entrepreneurship, and workforce development issues involved in the varied relationships between cultural industries and manufacturing. In the remainder of this article, we outline what such connections may involve, identifying directions for studying the intersection of cultural industries and small manufacturing.

\section{Cultural Production and Small Manufacturing: A Policy-driven Research Agenda}

In this section, we identify key areas for policy-driven research based on the preceding discussion. Our purpose is to delineate what we see as the key issues and the knowledge and policy gaps around support for the interaction between cultural industries and small manufacturers, including craft-based production. In doing so, we must recognize of course that there is no silver bullet policy formula-policies may take on different shape and priority in different places. For example, former industrial cities that continue to face economic challenges such as Manchester (UK), Cleveland (US), or Newcastle (Australia) must consider and emphasize a different set of policies than major cities with competitive real estate markets like London, New York, Sydney, or San Francisco (Gibson and Waitt 2012). Particularly because this area has received so little empirical study, in each region new research is needed to consider the unique factors that shape the cultural industries and their relation to craft and small manufacturing including industrial histories, competing land uses, political interests, and local networks. Similarly, policy will vary depending on the size and scale of a cultural industry-manufacturing cluster and the general economic climate in a region. In what follows, we discuss four areas to support a third narrative policy agenda around cultural production and small manufacturing. We focus on 1) (re)defining the field of cultural production, 2) land use and zoning, 3) cross-industry entrepreneurship and small business development, and 4) workforce development policy.

\section{(Re)defining the Field}

Any policy-focused research needs to first consider the policy environment itself, especially as the policy field of the cultural economy is weakly defined, contested, fragmented, and under-resourced. Identifying, let alone managing the 'ecosystem' within which the cultural economy operates has proved difficult for urban policy makers. Moreover, policy in this area is dispersed across different agencies - cultural, tourist, economic development, spatial regeneration and so on (Bianchini and Parkinson, 1993; O'Connor, 2013; O’Connor and Gu, 
2014b). As Pratt (2012) suggests, it is a sector that frequently falls between the silos of established policy frameworks; and its fluidity and complex mix of economic and cultural dynamics presents challenges for governance that are currently far from being met. Though an integral approach to the cultural economy as outlined by Pratt demands attention to social, cultural, and economic dimensions, the imaginaries of 'creative city' and 'creative industries' have tended overwhelmingly to an instrumental economic approach (O'Connor and Shaw, 2014; Foord, 2009). This raises questions not only of a new, more complex set of governance tools for a complex ecology, but a re-setting of the relationship between cultural policy as public policy in relation to urban development (O’Connor and Gibson, 2014).

Clearly then, rethinking the relationship of the cultural economy to manufacturing also requires a fundamental reconsideration of its policy narrative vis-à-vis the 'creative city' and cultural policy more generally. The third narrative policy that we describe above moves the creative city discourse away from a focus on attracting the creative class and supporting an economy of ideas and toward a concern with the dynamics of cultural production and the wider set of values involved in 'making things.'

But, it also requires consideration of a different set of actors. A refocused cultural economy policy around manufacturing and making requires cultural policymakers to engage with not only arts organizations, economic development, and planning, but also craft and manufacturing intermediaries working with industry, small business, workforce, labor unions, and education institution representatives (Clark, 2012). Whereas the old creative city discourse really did not entail much of a move from the traditional cultural policy emphasis on arts participation and consumption, the new narrative requires a deeper consideration of individual and collective creative production capabilities and the types of places, industry and workforce relations, and technology necessary in a cultural production 'ecosystem.' This is in line with what the original creative city agenda sought (Landry and Bianchini, 1995), but it is a very different creative city. While some cities - Austin, Denver, Toronto - have moved their cultural affairs agencies within economic development where they can better engage with redevelopment offices, there are no formal arrangements to our knowledge in which cities partner cultural policy with industrial and workforce development. Moreover, despite the connection to craft production, cities seeking to capitalize on the 'maker movement' have predominately done so as part of an innovation economy strategy (National League of Cities, 2015).

One area where cities can bring together the cultural policy knowledge-base with other relevant urban policy interests is around developing a better understanding of what actually defines the intersection of cultural production and small manufacturing. While there is disagreement over how to define the cultural industries (Markusen et al., 2008; O’Connor, 2010), there have nonetheless been efforts to document their location characteristics and clustering patterns (Chapin et al, 2010; Cook and Lazzeretti, 2008; Currid, 2012, Currid and Connelly, 2008; Grodach et al, 2014).

However, documentation of the presence and concentration of cultural industries and manufacturing across different regions has yet to occur. Such efforts are hampered by an appropriate and usable definition of small and 'cultural' manufacturing. Official statistics classify firms as manufacturing if they engage in 'the mechanical, physical, or chemical transformation of materials, substances, or components into new products'; they may 'use power-driven machines and materials-handling equipment' or 'transform materials or substances into new products by hand or in the worker's home' (US Census Bureau, 2016). 
This definition encompasses shop and craft work across the craft-manufacturing spectrum. From this, Friedman and Byron (2012) helpfully distinguish 'high-tech' and 'high-touch' manufacturing; Wolf-Powers and Lever (2016) similarly distinguish between inventor and artisan makers. These definitions differentiate between 'advanced manufacturing' that utilizes high-technology processes and 'cutting-edge materials' and work associated with smallbatch, 'hands-on' craft production. Friedman and Byron (2012) offer sample industries using NAICS data to demonstrate their approach.

From this, it is possible to distinguish firms and individuals engaged in the production of cultural products and materials including food and beverages, apparel, wood, paper and printing, metal, furniture, jewellery and musical instrument manufacture. Further, by crossing industry and occupational data, as others have done for the hi-tech and creative industries (Higgs and Cunningham, 2008; Chapple et al., 2004), a reasonably coherent picture can emerge of regional cultural-manufacturing economies. This process allows identification of firms engaged in the manufacture of cultural products and those working in cultural occupations in other sectors. For instance, those that manufacture cultural products (e.g. bread, furniture, prints) can be distinguished from those that require cultural occupational skill sets (e.g. specialized industrial sewing operations or sign making for the transportation industry).

We must also address the issue of size. A Brookings Institute study by Mistry and Byron (2010) define small manufacturing as firms with less than 100 employees. In the US, this encompasses just over $90 \%$ of all manufacturing. Manufacturing establishments that employ 20 or fewer people account for over $80 \%$ of manufacturing employment in New York and Los Angles and nearly 70\% in Chicago, all of which are important centres of US manufacturing (Mistry and Byron, 2010). The Australian Bureau of Statistics provides a definition that is more appropriate to contemporary conditions: small businesses, including manufacturing, possess 20 or fewer employees and micro-businesses employ fewer than 5 employees. Such a definition, based on existing establishment size class data, captures the large variety of small manufacturing activity and proxy for artisanal, craft-based production and larger scale operations within different sectors.

Analysis across different size classes is helpful in creating a more nuanced definition of small manufacturing. However, like all national industry and occupation databases breadth is traded for depth-it is difficult to capture quality of work and the larger question of production values that are central to artisanal manufacturing activity (Heying, 2008). One potential way to proxy this is to consult real estate occupancy data by firm type to get a better sense of workspace. For example, Melbourne conducts a Census of Land Use and Employment (CLUE) survey that provides establishment-based data for the city down to the block level. This includes employment data and information on building conditions such as year of construction, floor area, and type of use (office, retail, industrial, etc). While not perfect, this data reveals the conditions surrounding manufacturing and making process.

This approach, while not perfect, does help to build knowledge around what the cultural production-manufacturing field looks like before settling on precise definitions and categories. However, relying on statistical data alone is insufficient. Recent explorations of craft-based manufacturing sectors including surfboard-making and musical instrument production (Warren and Gibson 2013; Gibson and Warren 2016) illustrates that some enterprises will 'fall through the cracks' in existing statistical categories around both manufacturing and cultural industries. Knowledge is required beyond statistical data analysis, 
given that existing industry and occupation categories either split manufacturing activities from cultural production (thus perpetuating the semantic division between sectors that underpins the replacement narrative), or simply fail to capture discrete activities altogether.

\section{Land Use, Zoning and Cultural Production}

Building knowledge of the spatial and locational requirements and challenges to support cultural industries and small manufacturers is another important area for research that can complement statistical knowledge and inform policymaking. Both cultural industries and small manufacturers have specific needs that are overlooked with the emphasis on cultural consumption and the knowledge economy. This emphasis is in fact likely harming the development of cultural industry-manufacturing relationships.

Land use and zoning are a key challenge in this regard. Local governments increasingly convert scarce urban land from industrial uses to enable higher density and higher return residential and commercial development, but they do so at the expense of job quality and equality (Lester, et al., 2013). In the US, cities as diverse as Baltimore, Minneapolis, and San Francisco have all lost sizeable portions of industrial land in recent years (Leigh and Hoezel, 2012). Local governments often argue that the land use shift supports a changing, 'postindustrial' economy. However, Australian, UK, and US research demonstrates that in some cases the loss of manufacturing from central cities is due less to deindustrialization than to a failure to preserve industrial lands and regulate encroaching development (Curran, 2010; Ferm, 2016; Shaw, 2015; Wolf-Powers, 2005). This pushes many manufacturers out of central city areas while serving to justify the upzoning of industrial properties in favor of high-density residential property and 'mixed use' development.

Industrial displacement has a particular effect on small manufacturing and cultural production industries, which depend on central city locations. Many cities work from an outdated zoning system that does not recognize the changing shape of manufacturing nor cultural productiondespite the growing connections. As has been demonstrated in cities with strong property markets such as London, Melbourne, and New York, planning and rezoning around mixeduse land are part of a deliberate attempt to reshape the city for advances services, luxury residential, and upscale consumption (Ferm and Jones, 2016; Shaw, 2015; Shaw and Davies, 2014; Wolf-Powers, 2005). Cities target industrial lands for rezoning and redevelopment to maximize real estate values under the misperception that appropriate manufacturing land is in the outer suburbs and that central city industrial areas are no longer appropriate for manufacturing activity (Shaw and Davies, 2014).

Some manufacturing certainly requires large greenfield spaces with good transportation access on the periphery, but this is not universal. In reality, the urban context functions as a production factor for small manufacturers particularly those with ties to the cultural industries such as apparel, furniture, jewelry, and printing. As we elaborate below, because such businesses tend to be highly specialized, they often rely on close proximity to similar businesses, skilled labor, and a large urban market of consumers. The tendency of cultural product industries toward vertically disintegrated production encourages the high industry agglomeration found in urban areas (Pratt, 2004; Scott, 2000). For example, specialist woodworkers may benefit from a location near furniture makers or architecture and design firms, which also depend on close proximity for fast turnaround and direct interaction on custom-made parts for finished products. Others emphasize the importance of the built environment as critical to cultural production (Gibson, 2005; Hutton, 2008; O’Connor, 2004; 
O’Connor and Gu, 2010; Rantisi and Leslie, 2010; Warren and Gibson, 2014; Wood and Dovey, 2015). Compact urban design, active streetscapes, and public spaces are said to shape the creative process by generating opportunities for social exchange, which in turn helps producers with employment opportunities, contracts, partnerships, and innovative ideas. Distinctive place qualities also inspire and give identity to artistic products (Marotta et al., 2016). Finally, an urban location also means immediate access to dense local markets.

Clearly, zoning has economic implications that go beyond encouraging the 'highest and best use' of land. Therefore, it is important to build awareness among urban policymakers of the functional significance of an urban location to many cultural industries and manufacturers. It is similarly important to encourage cultural policymakers to understand that their remit around land use and zoning can go beyond affordable artist housing. Given the functional significance of an urban location to many cultural producers and manufacturers, policymakers should recognize that the 'post-industrial' city does not have to mean the complete evacuation of industry from the city. The growing attention to 'makers' and the work of manufacturing advocacy groups like SFMade and Portland Made is altering the perception of manufacturing from dirty and obsolete to new and innovative forms of small business and, in some cases, instigating new zoning policy. However, as has long been documented with artists, there is also a danger that makers contribute to gentrifying the places they seek to preserve for production (Marotta et al., 2016).

The challenge is that urban policy has focused primarily on consumption, amenities and real estate development, resulting in few attempts to address property speculation and conversion of industrial land despite research that shows an association between industrial land and job growth (Chapple, 2014). Chicago's Planned Manufacturing Districts and Industrial Corridors programs are long-standing and successful exceptions of industrial land preservation (Fitzgerald and Leigh, 2002). However, in few countries do governments specifically target places with existing small manufacturers. Nor do they pursue models that rethink land uses in the context of smaller-scale, cleaner manufacturing industries, although the German zoning system has long mixed 'nondisturbing' industry with other uses (Hirt, 2007).

Conceptions of urban redevelopment and infill can be rethought to incorporate compatible manufacturing and cultural production activities back into the urban core and peripheral suburbs. While the concept of including appropriate manufacturing in mixed use areas has received scant attention (Loomis, 1995), US cities are beginning to redesign their manufacturing districts to grow manufacturing jobs in the face of strong development pressure. In Portland, Oregon's Central Eastside Industrial Sanctuary, the City has allowed zoning variances that enabled knowledge industry firms to take over industrial buildings but is now seeking ways to enable these uses to coexist in an 'industrial ecosystem' (City of Portland, 2016). New York City is exploring zoning tools that permit increased density in industrial zones to allow for manufacturing expansion. It is also working on new, special mixed use 'creative economy districts' to allow compatible industrial, residential, and commercial space and 'vertical mixed-use zoning designations' that blend residential, commercial, and 'high performance industrial' uses (New York City Council, 2014). Similarly, San Francisco's San Francisco’s Production, Distribution and Repair (PDR) zone attempts to accommodate the growth of small manufacturers through a cross-subsidy on new, higher rent office development to support lower rent industrial space. Austin, TX, Los Angeles, and Vancouver, BC are pursuing similar policies in targeted areas as well. Given the pressures on urban land and the fact that the characteristics of small manufacturing and cultural industry firms are increasingly aligned, such practices hold promise. Policymakers 
would benefit from close observation of these experiments as they unfold.

\section{Cross-industry Entrepreneurship and Small Business Development}

Zoning is a crucial factor in supporting small manufacturers tied to cultural industries. However, factors related to entrepreneurship and small business development also need to be considered across a complex set of sectors. Policy in this arena is fundamental to encouraging small manufacturers and 'makers' given the predominately small scale of production, complex vertically disintegrated production processes, and consequent reliance on agglomeration and a 'collaborative social infrastructure' (Wolf-Powers et al., 2016; WolfPowers and Lever, 2016). This requires a rigorous analysis of the social interactions between cultural industries and small manufacturing that has yet to be conducted. There is now a volume of literature on the social factors of production in the arts and creative industries (Becker, 1982; Currid, 2007; Grodach, 2011; Kong, 2009; Lee, 2014; O’Connor, 2004; Scott, 2000) and an emerging literature studying the transition strategies of traditional manufacturing districts (Bryson and Ronayne, 2014; Tomlinson and Branston, 2014). However, this work has yet to examine the inter-industry networks and business development strategies among and between cultural industries and small manufacturers.

An extensive literature in urban studies and cultural economic geography seeks to explain the effects of agglomeration economies on cultural production particularly in terms of how firms leverage inter-industry networks (Clark, 2014; Grabher, 1993; MacKinnon et al. 2009; Piore and Sabel, 1984; Pratt, 2004; O’Conner, 2004; Scott, 2000; Storper, 2013; Storper and Scott, 2009). In brief, industry agglomerations enable actors to reduce costs through proximity by supporting networks and intermediaries that provide access to key services, supplies, and skilled labor. Additionally, arts and cultural industries research specifically concentrates on the importance of the social milieu in artistic production (Becker, 1982; Cummins-Russell and Rantisi 2012; Currid, 2007; Grodach, 2011; Lee, 2015; Kong, 2009; Lee, 2014; O’Conner, 2004; Scott, 2000). The work shows how complex divisions of labor and production are coordinated through tacit rules, norms, and institutional practices that define an industrial field (Storper and Christopherson, 1987; Storper and Venables, 2004; Thomas et al. 2013). This social infrastructure may provide opportunities for information and resource exchange, collaboration, skills development, and exposure to alternative ideas and practices, which propel product innovations and the use of novel production processes and materials.

As a consequence, a key focus for entrepreneurship and small business development in the context of highly agglomerated cultural industries is to restructure established models of arts and creative workspaces. Cities and cultural agencies in Australia, China, Europe and the US already sponsor such endeavours as a source of professional and business development and to preserve cultural clusters in the face of gentrification-related displacement (Ferm, 2016; Grodach, 2011; Gu, 2014; O’Connor and Gu, 2014b; Shaw, 2014). However, these spaces tend not to foster the cross-industry pollination that could enhance links to small manufacturers. A new creative and often collaborative workspace model, 'makerspaces,' can provide defacto small manufacturing support, and help us to locate the specific areas for policy intervention. Case studies of makerspaces show that they play the role of 'enabling entrepreneur' by providing access to specialized equipment and materials, business planning, sales and marketing assistance, learning and network opportunities, and seed funding to turn ideas into products (Wolf-Powers et al., 2016; Wolf-Powers and Lever, 2016). Such spaces are especially crucial for creative entrepreneurs who emphasize the importance of peer networking over traditional business consultants (Kuhn and Galloway, 2015). Additionally, 
creative and collaborative workspaces may provide a source of affordable space in the face of escalating property values and thus help maintain existing cultural clusters, but also are used by cities as a tool to foster new agglomerations (Ferm, 2016; Shaw, 2014). New York is the most high-profile in co-locating cultural industry and manufacturing space with Greenpoint Manufacturing \& Design Center and Brooklyn Navy Yard, but examples are dotted around the US, including Banbury Place in Eau Claire, Wisconsin and makerspaces such as ADX in Portland, Oregon.

While creative workspaces and makerspaces represent important sources of entrepreneurial support, intermediary organizations such as SFMade or Portland Made have helped to rebrand manufacturing and assist makers scale up their businesses. SFMade offers a series of business development workshops, sourcing referrals, works with the city's tourism agency to introduce visitors to local products, and helps to place small, local manufacturers in affordable space. New York City's economic development agency similarly hosts networking programs and events to showcase local products (Wolf-Powers and Lever, 2016).

In conjunction, the digitalisation of cultural content and the Internet may provide enhanced access to global markets and opportunities for learning, communication, and small business support. For example, the online marketplace Maker's Row helps match designers and small businesses with over 1,400 apparel, accessories, and furniture and home decor manufacturers around the US (Maker’s Row, 2016). Additionally, recent work shows how craft manufacturers and makers employ social media as tool to define and brand their work, build a customer base, and maintain work-community connections (Luckman, 2015; Marotta et al., 2016). Policymakers can develop similar programs that match contract manufacturers with small business and include social media marketing assistance as part of their suite of business development services.

However, the challenge - that has yet to be accomplished - is to develop a program that incorporates traditional manufacturing industries and workforces. This more difficult, but necessary task, addresses the question of the deeper economic and cultural fracturing of cities: 'innercity' versus periphery; creative/knowledge workers versus manual workers; white versus immigrant; elite vs underclass. The literature has intermittently identified the importance of local materials, skills, and know-how for the cultural industries themselves (Rantisi et al 2006; Rantisi and Leslie 2010). Yet, little work examines how these factors are shaped by interactions with manufacturing, and how long-standing industrial traditions and migrant labor patterns influence contemporary cultural production (Gibson, 2016).

Similarly, little research has specifically identified the potential 'spillovers' between cultural industries and different forms of manufacturing in terms of the mutual learning and support required for these sectors to flourish (e.g. in terms of design and production knowledge, use of materials, skill requirements). While some materials, equipment, and services might be based on external, price-related interactions, significant numbers of manufacture and craft firms are a) in a much more interactive relationship with cultural producers and rely on more bespoke and specialist services and $b$ ) these relationships are having a significant effect on the working practices and skills profile of these small manufacturing and craft firms (Warren 2014). Empirical research is needed to enhance our understanding of the specific range of knowledge, skills, and collaborations among cultural industries and small manufacturers. This is vital to locate opportunities to create new products and ideas and to identify training gaps and support mechanisms. These are significant research gaps that, if addressed, may entirely change the way we view and study clusters of creative production. 


\section{Workforce}

Workforce strategies are a direct compliment to those targeted at small business and an essential component of cultural industry-manufacturing policy. By focusing on developing and retooling manufacturing skill sets, workforce strategies are a direct response to the bifurcated division of labor under the knowledge economy and growing labor force inequalities in contemporary cities. On the one hand, programs can provide skills development for creative/artisan entrepreneurs and manufacturers. On the other, we need to focus on strategies that provide opportunities for dislocated workers in established or declining manufacturing industries - leather workers and bootmakers for example - and incorporate and draw upon their skills in new industries or in traditional industries reinvented through engaging with the logics of cultural and creative production (Gibson, 2016). A major challenge is that while growing manufacturing has potential to address workforce inequality, individual makers in and of themselves are not major employers. Studies have yet to be conducted to determine where and how the collective networks of makers and small manufacturers represent opportunities for job creation and the extent of new hires as businesses scale up and grow.

Policymakers need to know the extent to which traditional workforce programs around targeted training are most effective for manufacturing related to the cultural industries. Community colleges and other sources of vocational tertiary education offer hands-on courses in creative industries fields (photography and graphic design) and manufacturing (e.g. welding, metal working, textile fabrication) and connect students with job opportunities. They partner with industries to develop training programs, but this tends to be geared toward larger employers rather than the subclusters and sectoral cross-overs that define small cultural manufacturing. State and federal programs in the US, Australia, and elsewhere also provide self-employment initiatives to assist startup ventures. But, can existing programs such as these help train young people and place 'redundant' workers in cultural and manufacturing industries? Many manufacturing occupations like metalworking are learned on the job and small firms may not have the capacity to support training. This is another area where urban economic development and cultural policymakers can work together: to identify small manufacturing employment skill needs and deliver customized training to match the needs of existing cultural manufacturing clusters and help build career ladders.

A primary area for workforce policy also revolves around retooling older manufacturing skills and ways of 'making'. Workers in established but declining manufacturing industries can bring new knowledge to cultural production processes in terms of the tools, techniques, and familiarity with materials. In this regard, a helpful direction may be to pursue sectoral workforce programs like Chicago's Manufacturing Works initiative (Schrock, 2013). More radical, cities and states may reorganize some workforce programs along skill sets rather than traditional industry and firm-based approaches. Germany has long pursued this direction in its Beruf system, supporting broadly skilled workers in craft manufacturing. Such an approach places emphasis on production as a social activity defined by linked roles and occupations and problem solving and critical thinking rather than training around discrete, firm-oriented tasks (Toner, 2011). Still, such programs are not without challenges around political pressure and past institutional structures (Tomlinson and Branston, 2014).

\section{Conclusion}

As we write, electoral upheavals in the UK and United States demonstrate that more 
integrated approaches to urban policy that combine old and new industries, that speak to both creative/knowledge and manual workers and skills, are urgently needed. In this context of alarming economic and cultural schisms, this essay argues for a progressive policy agenda around cultural production. To this end, we draw attention to the under-studied relationships and interactions between cultural industries and small manufacturers and offer a research agenda focused on their interaction. A deeper understanding is needed of the work between urban cultural production and small manufacturing industries and their linkages with other forms of manufacturing to create strategies to support an environment for their future development.

Prior emphasis on creative industries has unhelpfully divorced 'mind' from 'body' tasks in cultural production - based on a replacement narrative that positions manufacturing as in inevitable decline, to be replaced by automation and cheap offshore labor, in contrast to knowledge and innovation activities, where the high value-added is said to exist (Carr and Gibson 2016). This emphasis cannot be sustained on either empirical grounds (given the shifting character of manufacturing itself), or against social justice criteria, given that the outcome has overwhelmingly been the continued marginalization of industrial workers and skills and exacerbated social inequality (Oakley 2006; Leslie and Catungal 2012).

Similarly, the consumption focus of much cultural economic policy-making has not only failed to nurture the culture-manufacturing nexus, but has often displaced it from the urban locations on which it depends (Shaw, 2013). As a result, many firms and self-employed craftspersons are forced to seek out less suitable locations. This harms economic development opportunities in many cities. It also reduces the potential to bring middle-class, skilled and semi-skilled job opportunities and incorporate more people into the creative economy - rather than relegate them to the sidelines as 'outmoded' workers forced into lowend service jobs.

In this way, we have sought to outline here a research agenda for progressive interpolations of the cultural economy, attuned to both the more complex nature of and interactions between small manufacturing and cultural industries, and the possibilities for more diverse job market outcomes. Examining the connections between cultural industries and small manufacturing is an important step toward the development of progressive and locally-rooted industry development strategies. Research can explore whether new possibilities exist for older manufacturing sectors, based on inherited industrial legacies and for retooling traditional manufacturing to take advantage of economic change and incorporate logics from cultural and innovation sectors. Such research may also provide an important intervention in the debate about the revitalisation of industrial lands - providing alternative narratives to those geared towards corporate investment and redevelopment of old manufacturing districts into high rise real estate and tourism and leisure landscapes. Research at the interface of small manufacturing and cultural industries can also identify new sources for product and process innovations and overlooked areas for training and skills development, job security and the capacity to support human flourishing. In sum, research focused on the growing intersection of urban manufacturing and cultural sectors presents important opportunities for rethinking both cultural policy and urban economic development outside of existing, and ultimately predictable and polarizing, frames of the cultural economy.

\section{References}

Anderson, C. (2012) Makers: The New Industrial Revolution. London: Random House. 
Atkinson, R. and Easthope, H. (2009) The consequences of the creative class: the pursuit of creativity strategies in Australia's cities. International Journal of Urban and Regional Research 33, 64-79.

Barnes, K, Waitt, G, Gill, N and Gibson, C (2006) Community and nostalgia in urban revitalisation: a critique of urban village and creative class strategies as remedies for social 'problems'. Australian Geographer, 37.3, 335-354.

Beauregard, R.A. (2005) The Textures of Property Markets: Downtown Housing and Office Conversions in New York City. Urban Studies, 42, 2431-2445.

Becker, H. (1982) Art Worlds. Berkeley, CA: University of California Press.

Berger, S. (2013) Making in America. Cambridge, MA: MIT Press.

Bryson JR, Taylor M and Cooper R (2008) Competing by design, specialization and customization: Manufacturing locks in the West Midlands (UK). Geografiska Annaler: Series B, Human Geography 90.2, 173-186.

Bryson, J.R. and Ronayne, M. (2014) Manufacturing carpets and technical textiles: routines, resources, capabilities, adaptation, innovation and the evolution of the British textile industry. Cambridge Journal of Regions, Economy and Society, 7.3, 471-488.

Butler, T. and Lees, L. (2006) Super-gentrification in Barnsbury, London: globalization and gentrifying global elites at the neighbourhood level. Transactions of the Institute of British Geographers, 31, 467-487.

Carr, C. and Gibson, C. (2016) Geographies of making: rethinking materials and skills for volatile futures. Progress in Human Geography 40, 3, 297-315,

Catungal, J. P., Leslie, D. \& Hii (2009) Geographies of Displacement in the Creative City: The Case of Liberty Village, Toronto. Urban Studies, 46.5-6, 1095-1114.

Causey, J. (2014) Brooklyn Makers: Food, Design, Craft, and Other Scenes from the Tactile Life. San Francisco: Chronicle.

City of Portland. (2016). Portland's Central Eastside. Bureau of Planning and Sustainability:

City of Portland.

Chapain, C., Cooke, P., De Propris, L., MacNeill, S. and Mateos-Garcia, J. (2010) Creative clusters and innovation: Putting creativity on the map. London: NESTA

Clark, J. (2012). Is there a progressive approach to innovation policy? Progressive Planning $190,17-22$.

Clark, J. (2014) Manufacturing by design: the rise of regional intermediaries and the reemergence of collective action. Cambridge Journal of Regions, Economy and Society 7(3), 433-448.

Clark, T.N. (2004) The City as an Entertainment Machine. Elsevier Ltd, Oxford.

Cooke, P. and Lazeretti, L. (eds.) (2008) Creative Cities, Cultural Clusters and Local Economic Development. Cheltenham: Edward Elgar.

Cummins-Russell, T. A. and Rantisi, N. M. (2012) Networks and place in Montreal's independent music industry. The Canadian Geographer, 56, 80-97.

Curran, W. (2010) In defense of old industrial spaces: manufacturing, creativity and innovation in Williamsburg, Brooklyn. International Journal of Urban and Regional Research 34.4, 871-885.

Currid, E. (2007) The Warhol Economy. Princeton, New Jersey: Princeton University Press.

Davidson, M. (2007) Gentrification as global habitat: a process of class formation or corporate creation. Transactions of the Institute of British Geographers, 32, 490-506.

Davidson, M. and Wyly, E. (2012) Class-ifying London: questioning social division and space claims in the post-industrial metropolis. City, 16, 395-421.

Evans, G. (2009) Creative cities, creative spaces and urban policy. Urban Studies, 46, 10031040.

Ferm, J. (2016) Preventing the displacement of small businesses through commercial 
gentrification: are affordable workspace policies the solution? Planning Practice \& Research, 31.4, 402-419.

Ferm, J., \& Jones, E. (2016). Beyond the post-industrial city: Valuing and planning for industry in London. Urban Studies, DOI: 10.1177/0042098016668778.

Fitzgerald, J., \& Leigh, N. G. (2002) Economic Revitalization: Cases and Strategies for Cities and Suburbs. Thousand Oaks: Sage.

Florida, R. L. (2002) The Rise of the Creative Class. Basic Books, New York.

Foord, J. (2009) Strategies for Creative Industries: an international review. Creative Industries Journal, 1.2, 91-113

Gibson, C. (2005) Recording studios: relational spaces of creativity in the city. Built Environment, 31.3, 258-273.

Gibson, C. (2012) Cultural economy: achievements, divergences, future prospects. Geographical Research, 50.3, 282-290.

Gibson, C (2015) Negotiating regional creative economies: academics as expert intermediaries advocating progressive alternatives. Regional Studies, 49.3, 476-479.

Gibson, C (2016) Material inheritances: how place, materiality and labor process underpin the path-dependent evolution of contemporary craft production. Economic Geography, DOI: $10.1080 / 00130095.2015 .1092211$.

Gibson, C, Carr, C and Warren, A (2015) Making things: manufacturing cultures and industrial cities, in J O’Connor and K Oakley (eds), The Routledge Companion to the Cultural Industries, London, Routledge.

Gibson, C. and Waitt, G. (2012) Urban cultural policy, city size and proximity, in Silver, D and Grodach, C (eds) The Politics of Urban Cultural Policy, Routledge, New York, pp. 122-137.

Gibson, C. and Warren, A. (2016) Resource-sensitive global production networks: reconfigured geographies of timber and acoustic guitar manufacturing. Economic Geography 92, 4, 430-454.

Grabher, G. (1993) The Embedded Firm: On the Socio-economics of Industrial Networks. Routledge, London.

Grodach, C. (2010) Beyond Bilbao: Rethinking flagship cultural development and planning in three California cities. Journal of Planning Education and Research, 29.3, 353-366.

Grodach, C. (2011) Art spaces in community and economic development: Connections to neighborhoods, artists, and the cultural economy. Journal of Planning Education and Research, 31.1, 74-85.

Grodach, C. (2012) Before and after the Creative City: The Politics of Urban Cultural Policy in Austin, Texas. Journal of Urban Affairs, 34.1, 81-97.

Grodach, C. (2013) Cultural Economy Planning in Creative Cities: Discourse and Practice. International Journal of Urban and Regional Research, 37.5, 1747-1765.

Grodach, C., Currid-Halkett, E., Foster, N., \& Murdoch, J. (2014) The location patterns of artistic clusters: A metro-and neighborhood-level analysis. Urban Studies, 51.13, 28222843.

Grodach, C. and Ehrenfeuct, R. (2016) Urban Revitalization: Remaking Cities in a Changing World. Routledge, Abingdon \& New York.

Grodach, C. and Loukaitou-Sideris, A. (2007) Cultural Development Strategies and Urban Revitalization: A Survey of US Cities. International Journal of Cultural Policy 13.4, 349369.

Grodach, C. and Silver, D. (eds). (2013) The Politics of Urban Cultural Policy: Global Perspectives. Routledge, Abingdon \& New York.

Gu, X. (2012) The Art of Re-Industrialisation in Shanghai, Culture Unbound, 4, 193-211.

Hackworth, Jason. (2014) The limits to market-based strategies for addressing land 
abandonment in shrinking American cities. Progress in Planning 90, 1-37.

Hatch, C. (2013) Competitiveness by design: An institutionalist perspective on the resurgence of a mature industry in a high wage economy. Economic Geography 89.3: 261-284.

Helper, S., Kreuger, T., and Weil, H. (2012) Why Does Manufacturing Matter? Which Manufacturing Matters? A Policy Framework. Brookings Institution.

Heying, C. (2010) Brews to Bikes: Portland's Artisan Economy. Ooligan Press, Portland.

Howkins, J. (2003) The Creative Economy: How People Make Money From Ideas. Penguin Global, New York.

Hudson, R. (2005) Rethinking change in old industrial regions: Reflecting on the experiences of North East England. Environment and Planning A 37, 581-596.

Hudson, R. (2012) Critical political economy and material transformation. New Political Economy 17.4, 373-397.

Hutton, T. (2008) The New Economy of the Inner City: Restructuring, Regeneration, and Dislocation in the Twenty-first-Century Metropolis. Routledge, New York.

Jacobs, J. (1961) The Death and Life of Great American Cities. Random House, New York.

Jakob, D. (2013) Crafting your way out of the recession? New craft entrepreneurs and the global economic downturn. Cambridge Journal of Regions, Economy and Society 6.1,127140.

Kenyon, Daphne A., Adam H. Langley, and Bethany P. Paquin. 2012. Rethinking Property Tax Incentives for Business. Lincoln Institute of Land Policy, Cambridge, MA.

Kong, L. (2009) Beyond networks and relations: Towards rethinking creative cluster theory. In L. Kong and J. O’Conner (eds.), Creative economies, creative cities: Asian-European perspectives, 61-75. Springer, Dordrecht, the Netherlands.

Koski, H., Marengo, L. and Mäkinen, I. (2012) Firm size, managerial practices and innovativeness: some evidence from Finnish manufacturing. International Journal of Technology Management 59, 2, 92-115.

Minha, L. (2015) Fostering connectivity: a social network analysis of entrepreneurs in creative industries. International Journal of Cultural Policy 21.2, 139-152.

Landry, C., \& Bianchini, F. (1995) The creative city. Demos, London.

Leigh, N. G., \& Hoelzel, N. Z. (2012) Smart Growth's Blind Side: Sustainable Cities Need Productive Urban Industrial Land. Journal of the American Planning Association, 78.1, 87-103.

Leslie, D. and Catungal, J.P. (2012) Social justice and the creative city: class, gender and racial inequalities. Geography Compass, 6, 111-122.

Lester, T. W., Kaza, N., and Kirk, S. (2014) Making Room for Manufacturing: Understanding

Threats to Industrial Land Conversion in Cities. unpublished paper.

Lloyd, R. (2010) Neo-bohemia: Art and commerce in the postindustrial city. New York: Routledge, $2^{\text {nd }}$ ed.

Loomis, J. (1995) Manufacturing Communities. Places 10.1, 48-57.

Luckman, S. (2013) The aura of the analogue in a digital age: women's crafts, creative markets and home-based labor after Etsy. Cultural Studies Review 19.1, 249-70.

Luckman, S. (2015) Craft and the Creative Economy. Palgrave Macmillan, London.

MacKinnon, D., Cumbers, A., Pike, A., Birch, K. and McMaster, R. (2009) Evolution in economic geography: institutions, political economy, and adaptation. Economic Geography 85.2, 129-150.

Marotta, S., Cummings, A. and Heying, C. (2016). Where Is Portland Made? The Complex Relationship between Social Media and Place in the Artisan Economy of Portland, Oregon (USA). M/C Journal 19 (3). http://journal.mediaculture.org.au/index.php/mcjournal/article/view/1083 
Mistry, N. and Byron, J. (2011) The Federal Role in Supporting Urban Manufacturing. Pratt Center.

Morozov, E. (2014) Making it - pick up a spot welder and join the revolution. The New Yorker. January 13, 2014. http://www.newyorker.com/magazine/2014/01/13/making-it-2 (accessed 6-10-15).

New York City Council. (2014). Engines of Economic Opportunity: Reinvigorating New York City's Manufacturing Zones for the 21st Century.

Noonan, D. (2013) How US cultural districts reshape neighborhoods. Cultural Trends 22.3-4, 203-212.

Oakley, K. (2006) Include Us Out-Economic Development and Social Policy in the Creative Industries. Cultural Trends 15, 255-273.

Oakley, K. and O’Connor, J (2015) Culture and the City. In Oakley, K. and O’Connor, J, The Routledge Companion to the Cultural Industries.

O’Connor, J. (2004) A Special Kind of City Knowledge: Innovative Clusters, Tacit Knowledge and the 'Creative City', Media International Australia 112, 131-149.

O’Connor, J. (2010) The Cultural and Creative Industries: A Literature Review. 2nd ed. Newcastle: Creativity, Culture and Education.

O’Connor, J. (2013) The Cultural and Creative Industries. In Stevenson, D. and Young, G. (eds.) The Ashgate Companion to Cultural Policy and Planning. Ashgate, Aldershot.

O’Connor, J. (2015) Intermediaries and Imaginaries in the Cultural and Creative Industries. Regional Studies 49.3, 374-387.

O’Connor, J \& Gibson M (2014) Culture, Creativity, Cultural Economy: A Review. A report for the Australian Council of Learned Academies, ACOLA, Melbourne, http://acola.org.au/index.php/australia-scomparative-advantage-contributing-reports (accessed 6-10-15).

O’Connor, J. and Gu, X. (2010) Developing a Creative Cluster in a Post-industrial City: CIDS and Manchester, The Information Society 26.2, 124-136.

O’Connor, J. \& Gu, X. (2014a) Creative industry clusters in Shanghai: a success story? International Journal of Cultural Policy 20.1, 1-20.

O’Connor, J. and Gu. X. (2014b) Making Creative Spaces: China and Australia: an Introduction. City, Culture and Society 5, 111-114.

O’Connor, J. and Shaw, K. (2014) What next for the Creative City? City, Culture and Society 5.3, 165-170.

Piore, M. J., and Sabel, C. F. (1984) The Second Industrial Divide: Possibilities for Prosperity. Basic Books, New York.

Pratt, A. (2012) The cultural and creative industries: Organisational and spatial challenges to their governance. DIE ERDE 143.4, 317-334.

Ponzini, D. and Rossi, U. (2010) Becoming a creative city: The entrepreneurial mayor, network politics and the promise of an urban renaissance. Urban Studies 47.5, 1037-1057.

Potts, Jason D. (2012) Creative industries and innovation in a knowledge economy. In Rooney, David J., Hearn, Gregory N., \& Kastelle, Timothy (Eds.) Handbook On The Knowledge Economy, Edward Elgar Publishing Limited, Cheltenham, United Kingdom.

Pratt, A. (2004) The cultural economy: a call for spatialized 'production of culture' perspectives. International Journal of Cultural Studies 7.1, 117-128.

Pratt, A. (2012) The cultural and creative industries: Organisational and spatial challenges to their governance. Die Erde 143.4, 317-334.

Rantisi, N. and Leslie, D. (2010) Materiality and creative production: the case of the Mile End neighborhood in Montreal, Environment and Planning A 42.12, 2924-2841.

Rantisi N. M., Leslie D., and Christopherson S. (2006) Placing the creative economy: Scale, politics, and the material. Environment and Planning A 38, 1789-97. 
Rusten G., Bryson, J.R. and Aarflot, U. (2007) Places through product and products through places: Industrial design and spatial symbols as sources of competitiveness. Norwegian Journal of Geography 61.3, 133-144.

Sassen, S. (2010) When places have deep economic histories. In Goldsmith, Stephen and Lynne Elizabeth (eds.) What We See, New Village Press, Oakland.

Sassen, S. (2012) Cities in a world economy. Sage, Thousand Oaks.

Schrock, G. (2013) Reworking Workforce Development Chicago's Sectoral Workforce Centers, Economic Development Quarterly 27.3, 163-178.

Scott, A. J. (2000) The cultural economy of cities: essays on the geography of imageproducing industries. Sage, Thousand Oaks.

Scott, A.J. (2004) Cultural-products industries and urban economic development: prospects for growth and market contestation in global context, Urban Affairs Review 39.4, 461-490.

Sennett, R. (2008) The Craftsman. Yale University Press, New Haven.

Shaw, K. (2013) Independent creative subcultures and why they matter. International Journal of Cultural Policy 19, 333-352.

Shaw, K. (2014) Melbourne's Creative Spaces program: Reclaiming the 'creative city' (if not quite the rest of it). City, Culture and Society 5.3, 139-147.

Shaw, K. (2015) Dereliction of duty: the impact of planned land redundancies on new urban manufacturing. Paper presented at the Association of American Geographers conference, Chicago, 25 April.

Storper, M. (2013) Keys to the city. Princeton University Press, Princeton NJ.

Storper, M. and Christopherson, S. (1987) Flexible Specialization and Regional Industrial Agglomerations: The Case of the U.S. Motion Picture Industry. Annals of the Association of American Geographers 77.1, 104-117.

Storper, M. and Scott, A. (2009) Rethinking human capital, creativity and urban growth. Journal of Economic Geography 9.2, 147-167.

Storper, M. and Venables, A. (2004) Buzz: face-to-face contact and the urban economy. Journal of Economic Geography 4.4, 351-370.

Thomas, N., Harvey, D.C. and Hawkins, H. (2013) Crafting the region: creative industries and practices of regional space. Regional Studies 47.1, 75-88.

Tomlinson, P.R. and Branston, J.R. (2014) Turning the tide: prospects for an industrial renaissance in the North Staffordshire ceramics industrial district. Cambridge Journal of Regions, Economy and Society 7.3, 489-507.

Toner, P. (2011) Workforce Skills and Innovation: An Overview of Major Themes in the Literature", OECD Education Working Papers, No. 55, OECD Publishing.

Van Heur, B. (2010) Creative networks and the city. Transcript Books, Bielefeld, Germany.

Warren, A (2014) Working culture: the agency and employment experiences of nonunionized workers in the surfboard industry, Environment and Planning A 46, 2300-2316

Warren, A. (2015) The embodied and emotional experiences of redundancy. Paper presented at the Association of American Geographers conference, Chicago, 25 April.

Warren, A. and Gibson, C. (2013) Crafting regional cultural production: emergence, crisis and consolidation in the Gold Coast surfboard industry. Australian Geographer 44.4, 365381.

Warren, A. and Gibson, C. (2014) Surfing places, surfboard-makers: craft, creativity and cultural heritage in Hawai 'i, California and Australia. University of Hawaii Press, Honolulu.

Watson, A. (2008) Global music city: knowledge and geographical proximity in London's recorded music industry. Area 40, 12-23.

Westbury, M. (2015) Creating Cities. Melbourne, Niche Press.

Wilson, D. (2009) Introduction: Racialized poverty in US cities: toward a refined racial 
economy perspective. The Professional Geographer 61, 139-149.

Wilson, D. and Keil, R. (2008) The real creative class. Social \& Cultural Geography 9.8, 841-847.

Wolf-Powers, L. and Levers, A. (2016) Planning, social infrastructure, and the maker movement: The view from New York City. Carolina Planning Journal 41, 38-52

Wolf-Powers, L., Schrock, G., Doussard, M., Heying, C, Eisenburger, M. and Marotta, S. (2016) The Maker Economy in Action: Entrepreneurship and Supportive Ecosystems in Chicago, New York and Portland. Portland, OR: Portland State University. 